\title{
Impacts of the Business Size on the Profit of Enterprises in the Mekong Delta
}

\author{
LÊE KHƯƠ' NINH \\ Associate Professor, Doctor of Philosophy, Cần Thơ University \\ Email: lekhuongninh@gmail.com \\ NGUYẼ̃N LÊ HOA TUYÊT \\ Bachelor of Art, Cần Thơ University \\ Email: nguyenlehoatuyet@gmail.com
}

\begin{abstract}
The paper aims to investigate impacts of the business size on the profit through primary data collated from 495 enterprises randomly chosen in the Mekong Delta. As the results indicate, the profit depends on the business size in the form of a cubic function. Additionally, the ratio of current assets to sales, the sales growth rate, the human resource quality, and the manager's attitude towards risks have positive relations with the profit. By contrast, the competitiveness responds negatively to the profit. Especially, impacts of unofficial costs on the profit are the $\cap$-shape of the square function. Based on estimates, some recommendations to enhance the profit are also provided.
\end{abstract}

Keywords: enterprises, business size, profit, ROS, growth rate, fixed assets, the Mekong Delta. 


\section{INTRODUCTION}

Profit is the primary target of all enterprises because it helps enterprises survive competition and develop. It has intrigued plenty of researchers who hope to devise a theoretical and empirical model. The paper also sheds light on the fact that profit is also affected by micro- and macro-economic factors. The complicated relationship between the size and the profit is controversial, which intrigues many researchers in the world.

As FitzRoy (1989) states, the relation between size and profit was positive due to the economic feature of the size. Yet Goddard et at. (2005) contended the opposite. Amato and Amato (2004), Amato and Burson (2007), Aggrey et al. (2010), and Becker-Blease et al. (2010) proved that size has both positive and negative impacts on profit. In other words, these researches maintain that profit depends on the size in the form of a nonlinear function.

However, whether or not stated conclusions are consistent with specific features of each country or region must be empirically tested in order to formulate appropriate policies which can help enterprises overcome setbacks caused by changes in the business size. Hence, this paper examines these issues using primary data of 495 randomly-chosen enterprises in the Mekong Delta.

\section{THEORETICAL BACKGROUND AND RESEARCH MODEL}

The core argument of profit's dependency on the size is the economies of scale. The economies of scale are related to reduction in costs when an enterprise expands its size and increase its output. This issue derives from the fact that the enterprise acquires a larger amount of input and attains longer-term contracts when expanding its size; and thereby enjoying a cheaper cost and higher profit. Together with expansion of size, the management is also highly specialized and thus the enterprise can perform more effectively. Moreover, big-sized enterprises, thanks to a stable source of high-quality inputs and a good employment of available resources, perform better than small-sized ones which can neither enjoy the economies of scale nor access financial sources or well-qualified human resources (FitzRoy, 1989; Yang and Chen, 2009).

Ballatine et al. (1993) analyzed the relationship between business size and the uncertainty about profitability. Accordingly, small-sized enterprises often face high uncertainty about profitability due to their managerial policy being sharply affected by the superior manager's own personalities, which makes the business operation biased, 
subjective and less comprehensive. In the meantime, the business operations in bigsized enterprises are not influenced by subjective opinions of any manager but by longterm strategies. Hence, the bigger the size, the higher the profit.

However, Amato and Amato (2004) and Amato and Burson (2007) state that with a sufficiently big set of enterprises of different sizes, small and big-sized enterprises can enjoy certain edges to develop themselves while medium-sized ones cannot. Specifically, a small-sized enterprise, by its flexible mobilization of capital, easily take advantage of missed market segments at a low cost. A big-sized one, despite being less flexible, can dominate the market by its prestige, market share, financial resources, and economies of scale. Meanwhile, medium-sized enterprises are neither as flexible as small-sized ones nor as qualified as big-sized ones to work out and implement strategies to lead the market (due to its lack of a well-known brand name and inability to make use of the economies of scale). Moreover, due to the fact that human resources and administration mode usually fail to adapt to changes in the size when an enterprise develops from a small to a medium one and that the enterprise often loses all sense of direction and even comes to a dead end, the profitability is adversely affected. In sum, the enterprise's profit will rise when the size reaches a certain level; and then decline to some extent. Yet when the size hits the second limit, the profit will go up again.

Given the aforementioned arguments, the following model is often utilized to test the profit's dependency on the size.

$$
L O I N H U A N=\beta_{0}+\beta_{1} Q U Y M O+\beta_{2} Q U Y M O^{2}+\beta_{3} Q U Y M O^{3}
$$

Where, LOINHUAN is the rate of return on sales (ROS); QUYMO is the business size (measured by the logarithm of the enterprise's asset value); $\mathrm{QUYMO}^{2}$ and $\mathrm{QUYMO}^{3}$ are respectively the square and cubic values of QUYMO. The coefficients $\beta_{1}$ and $\beta_{3}$ of QUYMO and QUYMO ${ }^{3}$ respectively are expected to be positive while the $\beta_{2}$ of QUYMO ${ }^{2}$ is expected to be negative.

However, as was stated above, profit is also affected by some other factors. Thus, in order to avoid missing significant factors, Model (1) is adjusted into:

$$
\begin{aligned}
& \text { LOINHUAN }=\beta_{0}+\beta_{1} Q U Y M O+\beta_{2} \text { QUYMO }{ }^{2}+\beta_{3} Q_{U Y M O}^{3}+ \\
& \beta_{4} \text { TSCDINH }+\beta_{5} \text { TSLUUDONG }+\beta_{6} \text { BOITRON }+\beta_{7} \text { BOITRON }^{2}+ \\
& \beta_{8} \text { TTRUONGDT }+\beta_{9} \text { CANHTRANH }+\beta_{10} \text { NHANLUC }+\beta_{11} \text { TUOIDN }+ \\
& \beta_{12} \text { THAIDORR }+\beta_{13} \text { HOCVAN }+\beta_{14} \text { THAMNIENQL }+\beta_{15} \text { SANXUAT }+ \\
& \beta_{16} \text { THUONGMAI }
\end{aligned}
$$


where, TSCODINH is the ratio of fixed assets to the sales. A large ratio implies that the enterprise has not effectively made the best use of fixed assets; and thus the profit is low (Demir, 2009), and the coefficient $\beta_{4}$ is expected to be negative.

TSLUUDONG is the ratio of current assets (i.e. cash, reserves, etc.) and the sales. With utilization of current assets, the enterprise can rapidly take profitable opportunities (e.g. hiring more labor, modifying the contingency reserves and inventory, promoting advertisement, and upgrading customer care, etc.) Moreover, with an abundant source of current assets, the enterprise need not secure bank loans and thus reduces loan interests, especially when the interest rate becomes volatile (Raheman and Nasr, 2007). The coefficient $\beta_{5}$ is therefore expected to be positive.

BOITRON is the greasing-the-wheels cost of a business (VND million p.a.). As in Svensson (2005), the unofficial cost will smooth operations of a bureaucratic administration mechanism, especially in countries with an ineffective legislation system; and enable enterprises to make use of profitable opportunities to gain high profit. Yet, greasing-the-wheels cost may adversely influence the profit because they can increase overheads and corrupt bureaucrats, who intentionally delay their must-do tasks in order to extract greasing-the-wheels fee from enterprises (Krueger, 1993). If any work is suspended, the enterprise can lose an immediate profitable opportunity, and expenditures on administrative procedures will decrease the profit. Therefore, the relationship between greasing-the-wheels cost and profit is a $\bigcap$-shaped function. This implies that the greasing-the-wheels cost can increase the profit to a certain extent; and then the profit will plunge if the greasing-the-wheels cost keeps soaring. Accordingly, the coefficient $\beta_{6}$ is expected to be positive and the coefficient $\beta_{7}$ to be negative.

TANGTRUONGDT denotes the growth rate of annual sales. Enterprises with high sale growth rate will enjoy high profit, implying a successful business (Guiso and Parigi, 1999; Demir, 2009). Thus, the coefficient $\beta_{8}$ is expected to be positive.

CANHTRANH bears value 1 (high competitive pressure) for an enterprise with PE larger than 14.76 (the mean of PE to the total number of samples) and zero otherwise (low competitive pressure) [1]. In the long run, the high competitive pressure compels the enterprise to renovate its technology, enhance the product quality, and promote advertising and promotion programs to avoid losing its market share; and thus the competitive pressure will positively affect the business in the long term. Yet in the 
short run, such supportive activities can increase cost and decrease profit (Glenn et al., 2001). In this case, the coefficient $\beta_{9}$ is expected to be negative.

NHANLUC is the ratio of labor with a university or higher degree to the total workforce. According to Doong et al. (2011), an enterprise with well-qualified workforce will achieve high productivity and performance, and the profit will rise accordingly. Hence, the coefficient $\beta_{10}$ is expected to be positive.

TUOIDN represents the enterprise's operational years at the time of study. An old enterprise can perform more effectively than a young one thanks to its edges on cost and market share (Ericson and Pakes, 1995). Yet, some old enterprises, especially state-run ones in transition economies, often stick to old-time mode of management, obsolete technology, and unqualified senior employees who depend on the government; and thus the business performance and profit are very low (Burki and Terrell, 1998; Yang and Chen, 2009). Hence, whether the coefficient $\beta_{11}$ is positive or negative depends on the strength of each factor.

THAIDORR is the top manager's attitude towards risks. It is measured by one of two scenarios: (i) investing an amount of money to gain an ROS of A\% (the value of THAIDORR is zero); and (ii) investing the same amount of money to gain an ROS of $2 \mathrm{~A} \%$ with the probability of 0.5 , or zero with the probability of 0.5 (the value of THAIDORR is 1.) Those opting for the first case are risk averse, so they look for a certainty even though it is impossible to bring in a high profit as expected. By contrast, advocates of the second option tend to accept risks to gain high profit. Hence, it is very difficult to decide which case is appropriate; empirically, the coefficient $\beta_{12}$ can be either positive or negative.

HOCVAN stands for the educational level of the top manager, which is measured by the number of years in schools. The higher the manager's educational level, the easier it is to acquire new knowledge of technology and management, and thereby utilizing available resources efficiently and gaining high profit (Agiomirgianakis and Papadogonas, 2011). Hence, the coefficient $\beta_{13}$ is expected to be positive.

THAMNIENQL is the number of years the top manager holds the office. According to Burki and Terrell (1998), management seniority positively affects the profit due to the fact that the longer the seniority, the fewer mistakes the manager makes in the decision-making process (especially when the manager are not sure of the market demand). Therefore, the coefficient $\beta_{14}$ is expected to be positive. 
SANXUAT bears value 1 for manufacturers and zero for other types of business. DICHVU bears value 1 for service providers and zero for others. These two variables are included in the model to test the differences in profit of three types of business (i.e. manufacturers, service providers, and traders). The coefficients $\beta_{15}$ of SANXUAT and $\beta_{16}$ of DICHVU can be either positive or negative depending on the real business climate.

\section{RESEARCH METHODOLOGY}

\section{a. Data Collection:}

Secondary data is collected from the GSO and departments of authority in the Mekong Delta provinces, and some existing researches.

The primary data is collated from some randomly-chosen enterprises in the Mekong Delta. Specifically, given the list of enterprises provided by the local Department of Planning and Investment and personal temporal and financial difficulties, the author just randomly opt for 1,000 enterprises for the study. For those in Cần Thơ, Vĩnh Long and Hậu Giang, the author conducted in-depth interviews on the basis of questionnaires which had been well adjusted. For those in remote areas where author cannot approach, the questionnaires were posted off to them. However, for several reasons (such as lack of address, wrong address, loss of letters, incomplete responses, etc.), there are just 495 enterprises to be employed in the study.

\section{b. Analytical Method:}

The descriptive statistical method is employed to describe the current situation of enterprises. Then, the OLS is performed to evaluate the model (2), which studies impacts of the size on the profit.

\section{RESEARCH RESULTS}

\section{a. Description of Research Sample:}

Of 495 chosen enterprises, state-owned ones constitute 3.67\%; joint-stock ones make up $28.11 \%$; private ones account for $25.87 \%$; and the remainder $(42.35 \%)$ are of other types of business. The average age of enterprises is 10.45 .

The average age of machinery and equipment of chosen enterprises is 6.18. Around $50.1 \%$ of machinery and equipment is imported and $49.9 \%$ domestically manufactured. Enterprises with abundant raw materials represent $34.63 \%$; those with rather sufficient 
raw materials being $55.50 \%$; and those lacking raw materials reaching $9.87 \%$. The shortage of input materials can adversely impinge on the business performance.

In terms of the stock of land area for production, according to the survey results, roughly $31.28 \%$ of enterprises possess a sufficient area for the long run; $25.51 \%$ of them own a stock of land which is enough for five years' use; and the land area of $33.95 \%$ of them just suffices for current use. Only a handful of enterprises (4.29\%) are unable to expand the premises; while $49.39 \%$ and $7.35 \%$ of enterprises respectively find it easy and extremely easy to do so. This implies the expansion of premises is quite easy for enterprises in the Mekong Delta due to the fact that the local land stock is abundant and cheap, and that many industrial parks are being built in the region. However, roughly $38.98 \%$ of enterprises cannot broaden their premises because of suspended zoning projects, opaque disclosures and complicated administrative procedures.

As the survey indicates, roughly 217 enterprises (43.84\%) must pay unofficial costs (smoothing fees) and 278 ones (56.16\%) do not. The average unofficial cost of an enterprise is VND154.53 million p.a. with the standard deviation of VND407.11 million, which shows a big disparity in the unofficial cost paid by enterprises. Albeit the unofficial cost is treated as a bribe, $47.26 \%$ of enterprises pay it voluntarily and $45.73 \%$ of them consider it as an unspoken and unwritten rule that must be strictly observed or be hampered otherwise; and the remaining $7.01 \%$ of enterprises deem it as a force of habit. In the event that it goes into a habit, the ratio of unofficial costs will certainly rise; and corrupted bureaucrats can take advantage of it, which, more adversely, can spoil the business climate and the community's belief in the government. Data collated from chosen enterprises are presented in Table 1.

Table 1: Data about Surveyed Enterprises

\begin{tabular}{lccccc}
\hline Criteria & Unit & Min & Max & Mean & $\begin{array}{c}\text { Standard } \\
\text { deviation }\end{array}$ \\
\hline Total assets & $\begin{array}{c}\text { VND } \\
\text { million }\end{array}$ & 716.80 & $720,150.00$ & $56,076.09$ & $86,080.52$ \\
Fixed assets & $\begin{array}{l}\text { VND } \\
\text { million }\end{array}$ & 26.00 & $330,000.00$ & $27,307.52$ & $47,976.99$ \\
Current assets & VND & 15.00 & $700,000.00$ & $28,768.56$ & $56,861.87$ \\
\hline
\end{tabular}




\begin{tabular}{|c|c|c|c|c|c|}
\hline & million & & & & \\
\hline Sales & $\begin{array}{l}\text { VND } \\
\text { million }\end{array}$ & 100.00 & $2,890,193.00$ & $104,121.30$ & $287,626.80$ \\
\hline Cost & $\begin{array}{l}\text { VND } \\
\text { million }\end{array}$ & 80.00 & $2,855,200.00$ & $92,977.25$ & $264,660.70$ \\
\hline Profit & $\begin{array}{l}\text { VND } \\
\text { million }\end{array}$ & $-5,682.00$ & $366,407.00$ & $11,144.05$ & $35,650.12$ \\
\hline ROS & $\%$ & -8.43 & 58.91 & 15.87 & 12.66 \\
\hline Workforce & Persons & 1.00 & $12,475.00$ & 224.20 & 836.56 \\
\hline Enterprise's age & Years & 1.00 & 79.00 & 10.45 & 9.67 \\
\hline Age of machinery & Years & 1.00 & 20.00 & 6.18 & 3.92 \\
\hline $\begin{array}{l}\text { Educational level of } \\
\text { the top manager }\end{array}$ & $\begin{array}{c}\text { Schooling } \\
\text { years }\end{array}$ & 5.00 & 20.00 & 15.59 & 2.32 \\
\hline $\begin{array}{l}\text { Age of the top } \\
\text { manager }\end{array}$ & Years & 22.00 & 76.00 & 45.55 & 9.09 \\
\hline $\begin{array}{l}\text { Seniority of the top } \\
\text { manager }\end{array}$ & Years & 1.00 & 37.00 & 11.18 & 7.08 \\
\hline
\end{tabular}

Source: Author's 2011 survey

\section{b. Analyzing Regression Results:}

As stated above, the paper aims to evaluate impacts of the size on the profit of enterprises in the Mekong Delta. Prior to evaluation, the multicollinearity and the heteroskedasticity are tested. With regard to the multicollinearity, the results indicate that the correlation coefficients of independent variables are smaller than 0.6; thus there is no multicollinearity. Moreover, the White test results in Table 2 reveal no heteroskedasticity.

Estimate results are reported in Table 2. The coefficient of QUYMO in the column (1) is statistically insignificant and coefficients of QUYMO and QUYMO ${ }^{2}$ in the column (2) are also insignificant. In the column (3), the coefficient of QUYMO is positive at the significance level of $5 \%$ while the coefficients of QUYMO ${ }^{2}$ and $\mathrm{QUYMO}^{3}$ are negative at the significance level of $1 \%$. This implies the profit is a 
cubic function of the business size, which is identical to the aforementioned findings of Amato and Amato (2004) and Amato and Burson (2007).

Given the regression results and by taking the derivative of the equation (2) with respect to QUYMO, we have:

$$
\partial L O I N H U A N / \partial Q U Y M O=158,388-32,066 Q U Y M O+1,590 Q U Y M O^{2} .
$$

Calculating this equation, the value of QUYMO is 8.66 (equivalent to the asset value of VND5.76 billion) and of QUYMO2 being 11.5 (equaling the asset value of VND98.72 billion). This result implies that: (1) with enterprises owning less than VND5.76bn, the bigger the size, the higher the profit; (2) with those owning from VND5.76bn to VND98.72bn, the bigger the size, the lower the profit; and (3) with those owing more than VND98.72bn, the bigger the size, the higher the profit.

\section{Table 2: Regression Results}

Dependent variable: ROS - return on sales (\%)

\begin{tabular}{|c|c|c|c|}
\hline Variable & (1) & (2) & (3) \\
\hline \multirow[t]{2}{*}{ Constant C } & 8.916 & -15.687 & -505.138 \\
\hline & (1.890) & $(-0.710)$ & $(-4.860)$ \\
\hline \multirow[t]{2}{*}{ QUYMO } & -0.557 & 4.536 & $158.388 * * *$ \\
\hline & $(-1.420)$ & (1.010) & $(4.910)$ \\
\hline \multirow[t]{2}{*}{ QUYMO $^{2}$} & & -0.258 & $-16.033 * * *$ \\
\hline & & $(-1.140)$ & $(-4.880)$ \\
\hline \multirow[t]{2}{*}{ QUYMO $^{3}$} & & & $0.530 * * *$ \\
\hline & & & $(4.810)$ \\
\hline \multirow[t]{2}{*}{ TSCODINH } & -0.002 & -0.002 & -0.010 \\
\hline & $(-0.030)$ & $(-0.030)$ & $(-0.140)$ \\
\hline \multirow[t]{2}{*}{ TSLUUDONG } & $0.140 * * *$ & $0.138 * * *$ & $0.152 * * *$ \\
\hline & $(4.880)$ & $(4.800)$ & $(5.360)$ \\
\hline \multirow[t]{2}{*}{ BOITRON } & $4.436 * * *$ & $4.358 * * *$ & $3.875 * * *$ \\
\hline & $(3.410)$ & $(3.350)$ & $(3.040)$ \\
\hline \multirow[t]{2}{*}{ BOITRON $^{2}$} & $-0.509^{* *}$ & $-0.499 * *$ & $-0.451 * *$ \\
\hline & $(-2.390)$ & $(-2.350)$ & $(-2.170)$ \\
\hline
\end{tabular}




\begin{tabular}{|c|c|c|c|}
\hline TTRUONGDT & $\begin{array}{c}0.060 * * * \\
(3.580)\end{array}$ & $\begin{array}{c}0.060 * * * \\
(3.560)\end{array}$ & $\begin{array}{c}0.059 * * * \\
(3.590)\end{array}$ \\
\hline CANHTRANH & $\begin{array}{c}-2.792 * * \\
(-2.390)\end{array}$ & $\begin{array}{c}-2.824 * * \\
(-2.420)\end{array}$ & $\begin{array}{c}-2.770 * * \\
(-2.420)\end{array}$ \\
\hline NHANLUC & $\begin{array}{l}0.047 * \\
(1.840)\end{array}$ & $\begin{array}{c}0.050^{*} \\
(1.930)\end{array}$ & $\begin{array}{c}0.056 * * \\
(2.230)\end{array}$ \\
\hline TUOIDN & $\begin{array}{c}-0.032 \\
(-0.530)\end{array}$ & $\begin{array}{c}-0.034 \\
(-0.560)\end{array}$ & $\begin{array}{c}-0.036 \\
(-0.600)\end{array}$ \\
\hline THAIDORR & $\begin{array}{l}2.542 * \\
(1.800)\end{array}$ & $\begin{array}{l}2.608^{*} \\
(1.840)\end{array}$ & $\begin{array}{c}2.747 * * \\
(1.990)\end{array}$ \\
\hline HOCVAN & $\begin{array}{c}0.536^{* *} \\
(2.110)\end{array}$ & $\begin{array}{l}0.546 * * \\
(2.150)\end{array}$ & $\begin{array}{c}0.434^{*} \\
(1.740)\end{array}$ \\
\hline THAMNIENQL & $\begin{array}{c}0.053 \\
(0.640)\end{array}$ & $\begin{array}{c}0.056 \\
(0.680)\end{array}$ & $\begin{array}{c}0.009 \\
(0.120)\end{array}$ \\
\hline SANXUAT & $\begin{array}{c}1.624 \\
(1.310)\end{array}$ & $\begin{array}{c}1.630 \\
(1.320)\end{array}$ & $\begin{array}{c}1.602 \\
(1.320)\end{array}$ \\
\hline DICHVU & $\begin{array}{c}2.953 * * \\
(2.430)\end{array}$ & $\begin{array}{c}2.850 * * \\
(2.340)\end{array}$ & $\begin{array}{c}2.828 * * \\
(2.380)\end{array}$ \\
\hline $\mathrm{N}$ & 495 & 495 & 495 \\
\hline $\mathrm{R}^{2}(\%)$ & 16.1 & 16.3 & 20.2 \\
\hline Adjusted $\mathrm{R}^{2}(\%)$ & 13.7 & 13.7 & 17.5 \\
\hline White test & 124.26 & 151.25 & 154.61 \\
\hline F-value & 6.58 & 6.23 & 7.56 \\
\hline Sig. & 0.00 & 0.00 & 0.00 \\
\hline
\end{tabular}

Source: The author's 2011 survey

N.B.: Values given in parentheses is the t-value. $* * *, * *, *$ denote the statistical significance of $1 \%$, $5 \%$ and $10 \%$ respectively. 
The coefficient of TSLUUDONG is positive at the significance level of $5 \%$. It implies that an abundant current asset can increase profit because the enterprise does not need loans and has ability to meet the market demand and expand the market share.

The fact that the coefficient of BOITRON is positive at the statistical significance of $1 \%$ and that of BOITRON ${ }^{2}$ being negative at the significance of $5 \%$ implies that the relationship between the profit and unofficial costs is $\bigcap$-shaped. The positive coefficient of TTRUONG_DT at the significance level of $5 \%$ and the negative coefficient of CANHTRANH at the significance level of $1 \%$ shows that the high competition will adversely impinge on the profit. Besides, the positive coefficient of NHANLUC at the significance of $5 \%$ also implies that a workforce with high educational level will increase the profit. The positive coefficient of THAIDORR at the significance level of $5 \%$ confirms a fact that if an enterprise can accept risks which are inevitable in business, and know how to be successful, its profit will be very high. Eventually, the DICHVU bearing a significance level of $5 \%$ expresses a difference in profit between service providers and other types of business (i.e. manufacturers and traders).

The regression results in Table 2 indicate that coefficients of TSCDINH, TUOIDN, HOCVAN, THAMNIENQL and SANXUAT can help identify their impacts on the profit; yet they are not statistically significant enough to be representative of all enterprises in the Mekong Delta.

\section{CONCLUSION AND RECOMMENDATION}

Profit is the vital factor to the sustainable development of an enterprise. During its operation, the size may fluctuate and impinge on the profit, either positively or negatively. The paper aims at testing impacts of the size on the profit with respect to 495 randomly-chosen enterprises in the Mekong Delta.

The estimate results indicate that the profit depends on the size in the shape of a cubic function. Specifically, an increase in the size can push the profit up to a certain limit; then the profit will drop until the size reaches the second limit at which the profit will increase according to the rise in size. Additionally, the ratio of current assets to the sales, growth rate of the sales, human resource quality, and attitude of senior manager towards risks has a positive relationship with the profit. By contrast, the competitiveness has a negative relation with the profit. Particularly, impacts of the unofficial cost on the profit are the $\bigcap$-shaped square function. 
Given estimate results, the author extends the following recommendations:

- During the corporate development, the size expansion is an indispensable trend; yet not all size expansion can positively influence the profit. Existing theories and the estimate results indicate that with regard to enterprises owning an asset value from VND5.76bn to VND98.72bn, the profit drops when the size rises because the enterprise cannot punctually renovate its mode of administration and human resource to match the new size. Therefore, in order to be profitable in this period, it is advised to promote the management competence (via training courses for example) and plan to hire professional managers when the business size starts to exceed the management competence.

- Furthermore, the decline in profit is also due to the fact that the enterprise loses the flexibility of a small-sized enterprise while it is not energetic enough to undertake an expansion strategy as a large-sized one can and so cannot identify its competitive edges. Hence, in order to be profitable, it is advised to establish competitiveness by strategies of cost control, differentiation, and concentration.

Regarding cost controls, the enterprise can improve the profit by minimizing costs. To do so, it is necessary to establish and mold a thrifty culture in the enterprise, optimize the use of machinery, employ the just-in-time system to monitor inventory, set up sustainable relationship with suppliers on the basis of mutual benefit. On expansion of the business size, it is needed to calculate appropriately investments in current assets so as to meet the market demand and reduce costs. An effective solution to which the enterprise can resort to weigh up investments in current assets is the real option theory (Lê Khương Ninh, 2010).

- Unlike the strategy of cost controls, the strategy of differentiation can increase the cost; yet if successful, it can raise profit and pave the way for the expansion of business size. It requires the enterprise to set up a high-quality department of research and development (R\&D) which is very rare in Vietnam. If this solution is unreachable, brand name management is also a good way to boost the profit (even if the product is not much different from its rival's ones. This can be explained by the fact that the difference does not derive from the quality or product models but from recognition of brand name, the quality of the distribution system and customer services.

- Eventually, the concentration strategy states that the best competitive method is to concentrate available resources and advantages on a certain product for a specific market 
segment to meet market demand and establish an appropriate business strategy which can boost the profit in the long run

\section{Note}

[1]: The PE ratio which was introduced by Boone (2008) and has been widely used to measure competitive pressure is the absolute value of the percentage of profit changed due to the $1 \%$ change in the marginal cost.

\section{References}

Aggrey, N., L. Eliab \& S. Joseph (2010), “The Relationship between Firm Size and Technical Efficiency in East Africa Manufacturing Firms," Journal of Sustainable Development in Africa, Vol.12(4), pp.226-236.

Agiomirgianakis, G.M. \& T.A. Papadogonas (2011), "Education and Firm Performance. Empirical Evidence from Greece," International Journal of Economic Research, Vol.8(2), pp.141152.

Amato, L.H. \& C.H. Amato (2004), "Firm Size, Strategic Advantage, and Profit Rates in US Retailing," Journal of Retailing and Consumer Services, Vol.11, pp.181-193.

Amato, L.H. \& T.E. Burson (2007), "The Effects of Firm Size on Profit Rates in the Financial Services," Journal of Economics and Economic Education Research, Vol.8(1), pp.67-81.

Ballantine, J.W., F.W.Cleveland \& C.T. Koeller (1993), "Profitability, Uncertainty and Firm Size," Small Business Economics, Vol.5, pp.87-100.

Becker-Blease, J.R., F.R. Kaen, A. Etebari \& H. Baumann (2010), "Employees, Firm Size and Profitability in U.S. Manufacturing Industries," Investment Management and Financial Innovations, Vol.7(2), pp.7-23.

Boone, J. (2008), “A New Way to Measure Competition”, The Economic Journal, Vol.118, pp.1245-1261.

Burki, A.A. \& D. Terrell (1998), "Measuring Production Efficiency of Small Firms in Pakistan," World Development, Vol.26(1), pp.155-169.

Demir, F. (2009), "Financialization and Manufacturing Firm Profitability under Uncertainty and Macroeconomic Volatility: Evidence from an Emerging Market," Review of Development Economics, Vol.13(4), pp. 592-609.

Doong, F., H.G. Shuh-Chyi \& Y. Wu (2011), “Are Social, Financial, and Human Capital Value Enhancing? Evidence from Taiwanese Firms," International Review of Economics and Finance, Vol.20, pp.395-405.

Ericson, R. \& A. Pakes (1995) "Markov-Perfect Industry Dynamics: A Framework for Empirical Work," Review of Economic Studies, Vol.62, pp.53-82. 
FitzRoy, F.R. (1989), "Firm Size, Efficiency and Employment: A Review Article," Small Business Economics, Vol.1, pp.75-80.

Glenn, J., K. Lee \& A. Singh (2001), "Persistence of Profitability and Competition in Emerging Markets," Economics Letters, Vol.15, pp.247-253.

Goddard, J., M. Tavakoli \& J.S. Wilson (2005), "Determinants of Profitability in European Manufacturing and Services: Evidence from a Dynamic Panel Model," Applied Financial Economics, Vol.15, pp.1269-1282.

Guiso, L. \& G. Parigi (1999), “Investment and Demand Uncertainty,” Quarterly Journal of Economics, Vol.114(1), pp.185-227.

Krueger, A.O. (1993), "Virtuous and Vicious Circles in Economic Development," Papers and Proceedings of the American Economic Association, LXXXIII, pp.351-356.

Lê Khương Ninh (2010), "Xác định giá trị của cơ hội đầu tư theo quan điểm quyền chọn thực," Nghiên cưu kinh tế, Vol.11(390), pp.44-49.

Raheman, A. \& M. Nasr (2007), "Working Capital Management and Profitability - Case of Pakistani Firms," International Review of Business Research Papers, Vol.3(1), pp.279- 300.

Svensson, J. (2005), "Eight Questions about Corruption," Journal of Economic Perspectives, Vol.19(3), pp.19-42.

Yang, C.H. \& K.H. Chen (2009), “Are Small Firms Less Efficient?” Small Business Economics, Vol.32, pp.375-395. 